\title{
TULANG RAWAN IKAN HIU: PENGARUH PEMBERIAN KONDROITIN SULFAT TERHADAP PROTEKSI MUKOSA LAMBUNG TIKUS PUTIH
}

\author{
Thamrin Wikanta", Lestari Rahayu"), dan Wanda M.Z."
}

\begin{abstract}
ABSTRAK
Telah dilakukan pengujian tentang pengaruh pemberian senyawa kondroitin sulfat terhadap perlindungan mukosa lambung tikus putih dengan dosis satu $\mathrm{g} / \mathrm{kg}$, dua $\mathrm{g} / \mathrm{kg}$, dan empat $\mathrm{g} / \mathrm{kg}$ bobot badan. Hasil pengujian menunjukkan bahwa kondroitin sulfat yang diberikan secara oral menimbulkan efek proteksi terhadap mukosa lambung tikus. Makin besar dosis kondroitin sulfat yang diberikan menimbulkan efek proteksi yang lebih baik. Dosis kondroitin sulfat $4 \mathrm{~g} / \mathrm{kg}$ bobot badan menimbulkan efek proteksi yang sama baiknya dengan sukralfat sebagai kontrol positif dengan dosis $500 \mathrm{mg} / \mathrm{kg}$ bobot badan. Hasil pengukuran $\mathrm{pH}$ lambung tikus menunjukkan bahwa kondroitin sulfat bersifat antasida atau menetralkan asam lambung karena memiliki $\mathrm{pH} 7,4$
\end{abstract}

\begin{abstract}
Shark cartilage: the effect of chondroitin sulfate intake on the stomach mucouse protection of white rats. By: Thamrin Wikanta, Lestari Rahayu, and Wanda M.Z.

The experiment on the effect of chondroitin sulfate intake on the stomach mucous protection of white rats with the doses of one $\mathrm{g} / \mathrm{kg}$, two $\mathrm{g} / \mathrm{kg}$, and four $\mathrm{g} / \mathrm{kg}$ of body weight had been carried out. The result showed that chondroitin sulfate given orally resulted in a protection effect to the rat stomach mucous. The higher the dose of chondroitin sulfate intake, the better the protection effect. The dose of chondroitin sulfate of $4 \mathrm{~g} / \mathrm{kg}$ of body weight gave a protection effect as good as sukralfate as a positif control with the dose of $500 \mathrm{mg} / \mathrm{kg}$ of body weight. Result of the rat stomach $\mathrm{pH}$ measurement showed that chondroitin sulfate acted as an antacide agent or netralizing gastric acid because it has the $\mathrm{pH}$ of 7.4 .
\end{abstract}

KEYWORDS: $\quad$ shark cartilage, chondroitin sulfate, stomach mucous protection.

\section{PENDAHULUAN}

Pada mukosa saluran cerna diproduksi mukus, yaitu sekret tebal yang melindungi mukosa lambung, yang terdiri atas air, elektrolit, dan polisakarida. Di antara bahan penyusun ini yang paling penting dan menentukan sifat mukus sebagai faktor pertahanan adalah polisakarida (Guyton, 1983). Menurut Tan \& Rahardja (1991), tukak lambung adalah salah satu jenis penyakit peradangan yang banyak ditemukan, baik pada orang dewasa maupun remaja, sebagai akibat dari terjadinya penurunan atau kerusakan ketahanan mukosa lambung. Dewasa ini perhatian dalam pengobatan tukak lambung mulai beralih kepada obat-obat sitoprotektif, yaitu obat yang dapat meningkatkan efek proteksi/perlindungan dan ketahanan mukosa saluran cerna, khususnya lambung. Menurut Rani (1989), obat-obat tersebut bersifat melindungi sel mukosa saluran cerna dari lesi/ luka yang terjadi, dan membantu meningkatkan aliran darah pada mukosa saluran cerna sehingga dapat mempercepat terjadinya regenerasi sel yang rusak.

Sukralfat (sukrosa aluminiumhidroksipolisulfat) adalah senyawa sintetik, salah satu jenis obat golongan protektif lokal yang digunakan untuk mengatasi penyakit tukak lambung. Sukralfat berupa serbuk putih, tak larut dalam air dan berbagai jenis pelarut organik, larut dalam asam, dan alkali (Dollery, 1991). Pada suasana asam lambung, sukralfat dapat membentuk pasta kental yang berikatan pada dasar tukak dan menjadi sawar (barrier) serta melindungi tukak terhadap difusi asam, pepsin, dan garam empedu (Daldiyono, 1993). Sifat proteksi sel mukosa oleh sukralfat diperoleh dengan meningkatkan produksi prostaglandin serta merangsang sekresi mukus dan bikarbonat. Karena mengandung aluminium, sukralfat dapat menyebabkan konstipasi (sukar buang air besar) ringan dan dapat menimbulkan toksisitas aluminium pada penderita gagal ginjal (Rani, 1989).

Untuk mengurangi efek samping penggunaan sukralfat tersebut, dicari obat alternatif lain. Kondroitin sulfat (mukopolisakarida) adalah senyawa alami hasil ekstraksi dari tulang rawan ikan hiu. Menurut Sugahara et al. (1992) dan de Waard et al. (1992), kondroitin sulfat adalah senyawa polisakarida utama yang terkandung di dalam tulang rawan ikan hiu

Peneliti pada Balai Penelitian Perikanan Laut 
Kondroitin sulfat merupakan senyawa polimer yang tersusun dari unit disakarida berulang di mana tiap unit disakarida mengandung $\mathrm{N}$-asetilgalaktosamin, asam glukuronat, dan gugus sulfat (Frisell, 1992; Murray et al., 1995; Pearson \& Young, 1992). Kedua senyawa, kondroitin sulfat dan sukralfat, sama-sama mengandung gugusan gula (heksosa) yang tersulfatasi. Menurut Szeja (1991), gula yang tersulfatasi inilah yang mempunyai khasiat sebagai obat antitukak. Adanya kemiripan struktur antara unit disakarida pada kondroitin sulfat dengan senyawa sukralfat (sukrosa aluminium hidroksipolisulfat) mendorong upaya pengujian senyawa kondroitin sulfat untuk digunakan sebagai obat antitukak lambung. Penggunaan kondroitin sulfat sebagai obat antitukak diharapkan dapat meningkatkan faktor pertahanan mukosa lambung, di samping yang sudah terdapat dalam tubuh secara alami.

Keberhasilan mengekstraksi senyawa kondroitin sulfat dari berbagai organ ikan hiu (Suparno et al., 1998a;1998b), mendorong upaya penggunaan senyawa tersebut untuk tujuan medis. Pengujian toksisitas akut dari kondroitin sulfat terhadap mencit putih menunjukkan bahwa senyawa tersebut termasuk golongan "Praktis Tak Beracun", berarti aman untuk digunakan sebagai obat (Lestari et al., 2000, in press). Adanya sifat polianionik yang besar dari kondroitin sulfat atau glikosaminoglikan, dan peranannya yang sangat penting di dalam fungsi biologis sel (Frisell, 1992; Murray et al., 1995; Pearson \& Young, 1990), membuat senyawa ini sangat menarik untuk diteliti lebih lanjut.

Dalam tulisan ini disajikan uraian has/ percobaan tentang pengaruh pemberian kondroitin sulfat hasil ekstraksi dari tulang rawan ikan hiu terhadap proteksi/ perlindungan mukosa lambung tikus putih

\section{BAHAN DAN METODE}

\section{Bahan}

Sediaan uji yang diteliti adalah senyawa kondroitin sulfat hasil ekstraksi dari tulang rawan ikan hiu (Carcharhinus limbatus) di Instalasi Penelitian Perikanan Laut Slipi, Jakarta. Sediaan ini berbentuk serbuk halus berwarna putih, sangat mudah larut dalam air, memberikan pH larutan sekitar 7,4 sebagaimana juga dikemukakan Dollery (1991) dan Schumm (1993)

\section{Hewan Uji}

Hewan uji yang digunakan adalah tikus putih galur Wistar jenis kelamin jantan, bobot badan 150-250 g, umur 16-24 minggu, diperoleh dari Bagian Histologi Fakultas Kedokteran Universitas Indonesia, Jakarta.

\section{Tahapan Penelitian (Lopez \& Motilva, 1993)}

Sejumlah 30 ekor tikus dibagi menjadi lima kelompok dan masing-masing kelompok terdiri atas enam ekor tikus. Sebelum dan selama percobaan berlangsung seluruh tikus diberi makanan standar yang didapatkan dari Bagian Histologi Fakultas Kedokteran Universitas Indonesia, Jakarta, dan diberi minum akuades matang

a. Tikus dipuasakan selama 24 jam

b. Bahan uji diberikan secara oral:

- Kelompok kontrol positif: suspensi sukralfat dengan dosis $500 \mathrm{mg} / \mathrm{kg}$ bobot badan.

Kelompok kontrol negatif: akuades

- Kelompok uji 1 : larutan zat uji kondroitin sulfat dengan dosis $1 \mathrm{~g} / \mathrm{kg}$ bobot badan.

- Kelompok uji 2 : larutan zat uji kondroitin sulfat dengan dosis $2 \mathrm{~g} / \mathrm{kg}$ bobot badan

Kelompok uji 3 : larutan zat uji kondroitin sulfat dengan dosis $4 \mathrm{~g} / \mathrm{kg}$ bobot badan.

c. Dua jam setelah pemberian bahan uji, diberi suspensi asetosal dengan dosis $200 \mathrm{mg} / \mathrm{kg}$ bobot badan dan kemudian tikus dikembalikan ke kandang.

d. Prosedur b dan c dilakukan selama dua hari

e. Pada hari ke-3 dan ke-4, tikus hanya diberikan larutan uji kondroitin sulfat, sukralfat atau akuades tanpa pemberian suspensi asetosal.

f. Pada hari ke-4, tiga jam setelah pemberian larutan uji kondroitin sulfat, sukralfat atau akuades, tikus dikorbankan dengan cara dibius dengan eter, dibedah dan lambungnya dikeluarkan.

g. Disuntikkan $5 \mathrm{~mL}$ larutan formalin 1\% ke dalam lambung tikus yang telah dikeluarkan dari tubuhnya, lalu didiamkan selama 10 menit.

h. Lambung dibuka pada bagian lengkung besar (kurvatura mayor), lalu dicuci dengan akuades perlahan-lahan untuk membersihkan sisa-sisa makanan yang tertinggal dalam lambung, kemudian direntangkan di atas papan datar. Tukak yang terbentuk pada dinding antrum dari lambung, berupa sayatan tipis tetapi tidak sampai terjadi perforasi, diamati jumlah dan tingkat keparahannya. Untuk memperjelas pengamatan tukak, digunakan kaca pembesar

i. Tukak lambung dievaluasi dengan metode pemberian nilai berdasarkan jumlah dan keparahan tukak (Sutjiatmo \& Sugiarso, 1996), seperti terlihat pada Lampiran 1 dan 2

\section{Analisis Data}

Untuk menganalisis data yang diperoleh, digunakan uji Kruskal-Wallis dan uji Dunn (Schefler, 1987). Uji Kruskal-Wallis adalah untuk menguji kemaknaan 
perbedaan beberapa sampel independen dengan data berskala ordinal. Uji Dunn (uji perbandingan ganda nonparametrik) adalah untuk membandingkan nilai peringkat rata-rata antara kelompok perlakuan

\section{HASIL DAN BAHASAN}

Hasil uji pengaruh pemberian kondroitin sulfat terhadap proteksi/perlindungan mukosa lambung berdasarkan jumlah dan keparahan tukak lambung adalah sebagai berikut:

\section{Jumlah tukak lambung}

Hasil uji pengaruh pemberian kondroitin sulfat terhadap proteksi mukosa lambung tikus putih berdasarkan jumlah tukak lambung, memberikan nilai seperti terlihat pada Tabel 1. Hasil penentuan peringkat nilai tukak terlihat pada Lampiran 3.

Berdasarkan hasil pengamatan terlihat adanya beberapa peringkat nilai yang sama. Hasil uji statistik menunjukkan adanya perbedaan sangat nyata antar kelompok perlakuan, seperti terlihat pada Tabel 2.

Tabel 1. Hasil penilaian tukak lambung berdasarkan jumlah tukak pada tiap kelompok perlakuan

Table 1. Score of peptic ulcer based on the total ulcer on each group of treatment

\begin{tabular}{cccccc}
\hline $\begin{array}{c}\text { Ulangan } \\
\text { Replication }\end{array}$ & \multicolumn{6}{c}{ Kelompok perlakuan (Group of treatment) } \\
\cline { 2 - 6 } 1 & I & II & III & IV & V \\
2 & 5 & 3 & 2 & 1 & 1.5 \\
3 & 4 & 4 & 1.5 & 1 & 1 \\
4 & 4 & 4 & 1.5 & 1 & 1 \\
5 & 4 & 3 & 2 & 1 & 1.5 \\
6 & 5 & 3 & 1.5 & 1.5 & 1 \\
& 5 & 4 & 2 & 1.5 & 1 \\
\hline
\end{tabular}

Kelompok perlakuan 1: diberi akuades (kontrol negatif)

Group of treatment 1: given aquadest (negative control)

Kelompok perlakuan II : diberi larutan kondroitin sulfat dengan dosis $1 \mathrm{~g} / \mathrm{kg}$ bobot badan Group of treatment II : given chondroitin sulfate solution dose of $1 \mathrm{~g} / \mathrm{kg}$ body weight Kelompok perlakuan III: diberi larutan kondroitin sulfat dengan dosis $2 \mathrm{~g} / \mathrm{kg}$ bobot badan Group of treatment III: given chondroitin sulfate solution dose of $2 \mathrm{~g} / \mathrm{kg}$ body weight Kelompok perlakuan IV : diberi larutan kondroitin sulfat dengan dosis $4 \mathrm{~g} / \mathrm{kg}$ bobot badan Group of treatment IV: given chondroitin sulfate solution dose of $4 \mathrm{~g} / \mathrm{kg}$ body weight Kelompok perlakuan $\mathrm{V}$ : diberi sukralfat dosis $500 \mathrm{mg} / \mathrm{kg}$ bobot badan (kontrol positif). Group of treatment $V$ : given sukralfat dose of $500 \mathrm{mg} / \mathrm{kg}$ body weight (positive control).

Tabel2. Hasil uji statistik tukak lambung berdasarkan jumlah tukak lambung pada tiap kelompok perlakuan

Table 2. Statistical analysis result of peptic ulcer based on the total ulcer on each group of treatment

\begin{tabular}{ccccccc}
\hline \multirow{2}{*}{$\begin{array}{c}\text { Kelompok } \\
\text { perlakuan } \\
\text { Group of treatment }\end{array}$} & $\begin{array}{c}\text { Peringkat } \\
\text { rata-rata } \\
\text { Mean rank }\end{array}$ & \multicolumn{5}{c}{$\begin{array}{c}\text { Beda hasil peringkat rata-rata } \\
\text { Difference of mean rank }\end{array}$} \\
\cline { 3 - 7 } I & 26.8 & \multicolumn{1}{c}{ I } & II & III & IV & V \\
II & 22.2 & $4.6^{*}$ & - & & \\
III & 14.5 & $12.3^{*}$ & $7.7^{*}$ & - & \\
IV & 7 & $19.8^{* *}$ & $15.2^{* *}$ & $7.5^{*}$ & - & \\
V & 7 & $19.8^{* *}$ & $15.2^{* *}$ & $7.5^{*}$ & 0 & - \\
\hline
\end{tabular}

= berbeda nyata (significant difference) $(p=0.05)$;

= berbeda sangat nyata (significant difference) $(p=0.01)$ 


\section{Keparahan tukak lambung}

Hasil uji pengaruh pemberian kondroitin sulfat terhadap proteksi/perlindungan mukosa lambung tikus putih berdasarkan keparahan tukak lambung, memberikan nilai seperti terlihat pada Tabel 3 . Hasil penentuan peringkat nilai tukak terlihat pada Lampiran 4.

Berdasarkan hasil pengamatan terlihat adanya beberapa peringkat nilai yang sama. Hasil uji statistik menunjukkan adanya perbedaan sangat nyata antar kelompok perlakuan, seperti terlihat pada Tabel 4.

Hasil uji efek proteksi/perlindungan dari kondroitin sulfat terhadap mukosa lambung tikus putih berdasarkan jumlah dan keparahan tukak, dapat dilihat pada Tabel 1 dan 3. Data yang diperoleh dari percobaan, dianalisis menggunakan metode statistik Kruskal-Wallis untuk melihat adanya perbedaan antar kelompok perlakuan. Kemudian uji ini dilanjutkan dengan uji Dunn atau uji perbandingan ganda. Antar kelompok perlakuan berbeda sangat nyata. Hasil uji statistik terlihat pada Tabel 2 dan 4
Makin kecil nilai yang diperoleh makin baik efek proteksinya. Kelompok kontrol negatif mempunyai nilai yang paling besar. Kelompok zat uji kondroitin sulfat dosis $1 \mathrm{~g} / \mathrm{kg}$ bobot badan mempunyai nilai yang hampir sama dengan kelompok kontrol negatif Sedangkan kelompok zat uji kondroitin sulfat dosis 4 $\mathrm{g} / \mathrm{kg}$ bobot badan mempunyai nilai yang sama dengan kelompok kontrol positif. Makin besar dosis zat uji kondroitin sulfat yang diberikan, makin kecil nilainya $\mathrm{Hal}$ ini berarti, makin besar dosis zat uji kondroitin sulfat yang diberikan, makın baik efek proteksinya terhadap mukosa lambung

Antara kelompok zat uji dosis $4 \mathrm{~g} / \mathrm{kg}$ bobot badan dengan kelompok kontrol positif tidak ada perbedaan bermakna. Dengan demikian, zat uji kondroitin sulfat dosis $4 \mathrm{~g} / \mathrm{kg}$ bobot badan mempunyai efek proteksi sama baiknya dengan obat pembanding yang digunakan dalam percobaan ini, yaitu sukralfat dengan dosis $500 \mathrm{mg} / \mathrm{kg}$ bobot badan.

Pada percobaan ini selain diuji efek proteksi dari kondroitin sulfat terhadap mukosa lambung, juga

Tabel 3. Hasil penilaian tukak lambung berdasarkan keparahan tukak pada tiap kelompok perlakuan

Table 3. Score of peptic ulcer based on the seriousness of ulcer on each group of treatment

\begin{tabular}{clllll}
\hline $\begin{array}{c}\text { Ulangan } \\
\text { Replication }\end{array}$ & \multicolumn{5}{c}{ Kelompok perlakuan (Group of treatment) } \\
\cline { 2 - 6 } & I & II & III & IV & V \\
\hline 1 & 5 & 5 & 2 & 1 & 1.5 \\
2 & 5 & 5 & 1.5 & 1 & 1 \\
3 & 4 & 5 & 1.5 & 1 & 1 \\
4 & 5 & 4 & 2 & 1 & 1.5 \\
5 & 5 & 4 & 1.5 & 1.5 & 1 \\
6 & 4 & 4 & 2 & 1.5 & 1 \\
\hline
\end{tabular}

Tabel 4. Hasil uji statistik tukak lambung berdasarkan keparahan tukak pada tiap kelompok perlakuan Table 4. Statistical analysis result of peptic ulcer based on the seriousness of ulcer on each group of treatment

\begin{tabular}{|c|c|c|c|c|c|c|}
\hline \multirow{2}{*}{$\begin{array}{c}\text { Kelompok } \\
\text { perlakuan } \\
\text { Group of treatment }\end{array}$} & \multirow{2}{*}{$\begin{array}{c}\text { Peringkat } \\
\text { rata-rata } \\
\text { Mean rank }\end{array}$} & \multicolumn{5}{|c|}{$\begin{array}{l}\text { Beda peringkat rata-rata } \\
\text { Difference of mean rank }\end{array}$} \\
\hline & & $T$ & $\pi$ & III & IV & $\mathrm{v}$ \\
\hline 1 & 25 & - & & & & \\
\hline$\|$ & 24 & $1.0^{*}$ & - & & & \\
\hline III & 14.5 & $10.5^{\star}$ & $9.5^{\star}$ & - & & \\
\hline IV & 7 & $18.0^{\star \star}$ & $17.0^{\star \star}$ & $7.5^{\star}$ & - & \\
\hline V & 7 & $18.0^{\star \star}$ & $17.0^{\star \star}$ & $7.5^{\star}$ & 0 & - \\
\hline
\end{tabular}

= berbeda nyata (significant difference) $(p=0.05)$

$=$ berbeda sangat nyata (significant difference) $(p=0.01$ ) 
dilakukan pengukuran $\mathrm{pH}$ cairan lambung setelah lambung dibuka (Tabel 5). Hasil analisis statistik menunjukkan adanya perbedaan sangat nyata antar kelompok perlakuan, seperti terlihat pada Tabel 6 .

Antara kelompok kontrol negatif dengan kelompok kondroitin sulfat dosis $1 \mathrm{~g} / \mathrm{kg}$ bobot badan terdapat perbedaan nyata, sedangkan antara kelompok kontrol negatif dengan kelompok khindroitin sulfat dosis $2 \mathrm{~g} /$ $\mathrm{kg}$ bobot badan dan $4 \mathrm{~g} / \mathrm{kg}$ bobot badan terdapat perbedaan yang sangat nyata. Hal ini diduga karena kondroitin sulfat bersifat agak basa $(\mathrm{pH} 7,4)$, sehingga dapat menaikkan pH cairan lambung. Dosis kondroitin sulfat $1 \mathrm{~g} / \mathrm{kg}$ bobot badan memberikan pengaruh relatif sedikit terhadap $\mathrm{pH}$ cairan lambung, sedangkan dosis $2 \mathrm{~g} / \mathrm{kg}$ bobot badan dan dosis $4 \mathrm{~g} / \mathrm{kg}$ bobot badan memberikan pengaruh sangat besar terhadap $\mathrm{pH}$ cairan lambung.

Antara kelompok kontrol negatif dengan kelompok kontrol positif tidak ada perbedaan nyata, hal ini berarti sukralfat tidak bersifat antasida (menetralkan cairan lambung). Antara kelompok kondroitin sulfat dosis 2 $\mathrm{g} / \mathrm{kg}$ bobot badan dan dosis $4 \mathrm{~g} / \mathrm{kg}$ bobot badan tidak ada perbedaan nyata. Ini berarti kedua dosis tersebut sama kuatnya dalam menetralkan asam lambung.

\section{KESIMPULAN}

Kondroitin sulfat hasil ekstraksi dari tulang rawan ikan hiu yang diberikan secara oral pada tikus putih jantan, mempunyai efek proteksi/perlindungan terhadap mukosa lambung tikus.

Makin besar dosis yang diberikan pada tikus, makin baik efek proteksinya. Kondroitin sulfat dosis $4 \mathrm{~g} / \mathrm{kg}$ bobot badan memberikan efek proteksi sama baiknya dengan sukralfat dosis $500 \mathrm{mg} / \mathrm{kg}$ bobot badan.

Hasil pengukuran $\mathrm{pH}$ lambung tikus menunjukkan bahwa senyawa kondroitin sulfat bersifat antasida atau menetralkan asam lambung karena memiliki pH 7,4

Sifat antasida dari kondroitin sulfat tidak begitu kuat karena $\mathrm{pH}$ yang ditimbulkan tidak terlampau

Tabel 5. Hasil pengukuran $\mathrm{pH}$ cairan lambung

Table 5. Result of the stomach liquid pH measurement

\begin{tabular}{cccccc}
\hline \multirow{2}{*}{$\begin{array}{c}\text { Ulangan } \\
\text { Replication }\end{array}$} & \multicolumn{5}{c}{ Kelompok perlakuan (Group of treatment) } \\
\cline { 2 - 6 } & I & II & III & IV & V \\
\hline 1 & 3 & 4 & 7 & 6 & 3 \\
2 & 4 & 4 & 6 & 6 & 4 \\
3 & 3 & 4 & 6 & 6 & 4 \\
4 & 4 & 4 & 6 & 5 & 3 \\
5 & 3 & 5 & 5 & 6 & 4 \\
6 & 3 & 5 & 6 & 5 & 3 \\
\hline Total (Total) & 20 & 26 & 36 & 34 & 21 \\
\hline Rata-rata (Mean) & 3.33 & 4.33 & 6 & 5.67 & 3.5 \\
\hline
\end{tabular}

Tabel6. Hasil uji statistik nilai pH cairan lambung

Table 6. Statistical analysis result of the stomach liquid $\mathrm{pH}$ measurement

\begin{tabular}{|c|c|c|c|c|c|c|}
\hline \multirow{2}{*}{$\begin{array}{c}\text { Kelompok } \\
\text { perlakuan } \\
\text { Group of treatment }\end{array}$} & \multirow{2}{*}{$\begin{array}{c}\mathrm{pH} \text { rata-rata } \\
\text { Mean } \mathrm{pH}\end{array}$} & \multicolumn{5}{|c|}{$\begin{array}{c}\text { Beda pH rata-rata } \\
\text { Difference of mean } \mathrm{pH}\end{array}$} \\
\hline & & 1 & II & III & IV & V \\
\hline 1 & 3.33 & - & & & & \\
\hline II & 4.33 & $1.0^{*}$ & - & & & \\
\hline III & 6 & $2.67^{\star \star}$ & $1.67^{\star}$ & - & & \\
\hline IV & 5.67 & $2.34^{\star \star}$ & $1.34^{\star \star}$ & 0.33 & - & \\
\hline V & 3.5 & $0.17^{\star \star}$ & $0.83^{* *}$ & $2.5^{* *}$ & $2.17^{\star \star}$ & - \\
\hline
\end{tabular}

\footnotetext{
${ }^{*}=$ berbeda nyata (significant difference) $(p=0.05)$

${ }^{* *}=$ berbeda sangat nyata (significant difference) $(p=0.01)$
} 
basa. Sifat sitoproteksi sangat menonjol karena kondroitin sulfat bersifat anionik kuat seperti elektrolit dan juga kemampuannya untuk membentuk pasta dan dapat berikatan pada dasar tukak membentuk sawar (barrier) sehingga dapat melindungi tukak dari serangan asam, pepsin dan garam-garam empedu

Sifatnya yang alamiah dan tidak mengandung aluminium maka kondroitin sulfat diharapkan tidak menimbulkan efek samping yang dapat menyebabkan konstipasi dan tidak bersifat toksik bagi penderita ginjal.

\section{DAFTAR PUSTAKA}

Daldiyono. 1993. Penatalaksanaan Gastritis dan Ulkus Peptikum. Pendidikan Kedokteran Berkelanjutan Uji Diri. p. 1-29.

de Waard, P., Vliegenthart, J.F.G., Harada, T., and Sugahara, K. 1992. Structural studies on sulfated oligosaccharides derived from the carbohydrate-protein linkage region of chondroitin 6 -sulfate proteoglycans of shark cartilage. II. Seven compounds containing 2 or 3 -sulfate residues. J. Biol Chem. 267: 6036-6043.

Djuwantoro, D. 1992. Diagnosis dan pengobatan tukak peptik. Cermin Dunia Kedokteran 79. p. 14-17

Dollery. S.C. 1991. Therapeutic Drugs. Churchill Livingstone, New York. p. 107-110.

Frisell, W.R. 1992. Human Biochemistry. Mcmillan Publishing Co. Inc., New York. p. 139-149.

Gleason, M.N. 1969. Clinical Toxicology of Commercial Product. Baltimore William and Wilkins. p. 3-4.

Guyton. A.C. 1983. Buku Teks Fisiologi Kedokteran. Bag. 2. Edisi 5. Diterjemahkan: A. Dharma dan P. Lukmanto. ECG Penerbit Buku Kedokteran, Jakarta. p. 327-339

Lestari, R., Wanda, M.Z., dan Wikanta, T. 2000. Toksisitas Akut Khondroitin Sulfat Hasil Ekstraksi dari Tulang Rawan Ikan Hill. (Jurnal volume ini)

Lopez, A and Motilva, V. 1993. Gastroprotection and prostaglandin E2 generation in rats by flavonoids of districhia viscosa. Planta Medica Journal of Medicinal Plant Research 6 (59): 497-500.

Murray, R.K., Granner, D.K., Mayes, P.A., and Rodwell, V.W. 1995. Biokimia Harper (Harper's Review of Bio- chemistry). Edisi 22. Alih bahasa: A. Hartono. EGC Penerbit Buku Kedokteran, Jakarta. p. 716-737

Mutschler, E. 1991. Dinamika Obat. Penerbit ITB. Bandung. p. 521-535

Pearson, A.M. and Young, R.B. 1990. Muscle and Meat Biochemistry. Academic Press, London. p. 371-373

Rani. A.A. 1989. Naskah Lengkap Gastritis Kronik. Peranan Campylobacter Pylory dan Sitoproteksi. Fakultas Kedokteran Universitas Indonesia, Jakarta p. 1-21

Schefler, W.C. 1987. Statistika untuk Biologi. Farmasi. Kedokteran dan IImu yang Bertautan. Terjemahan Suroso. Penerbit ITB, Bandung. p. 138-142.

Schumm, D.E. 1993. Intisari Biokimia. Alih bahasa Sadikin, M.. Binarupa Aksara. p. 232-235

Sugahara, K., Oki, Y., Harada, T., de Waard, P., and Vliegenthart, J.F.G. 1992. Structural studies on sulfated oligosaccharides derived from the carbohydrate-protein linkage region of Chondroitin 6-sulfate proteoglycans of Shark Cartilage. I. Six compounds containing $\mathrm{O}$-or 1-sulfate and/or phosphate residue. J. Biol. Chem. 267: 6027-6035.

Suparno, Saleh, M., and Murdinah. 1998a. Extraction and isolation of chondroitin from various tissues of elasmobranches. Paper presented in APFIC Symposium on Fish Utilization. Beijing, 24-26 September 1998

Suparno, Murdinah. dan Saleh, M. 1998b. Kandungan khondroitin pada beberapa bagian tubuh ikan hiu (Carcharhinus limbatus) yang berbeda ukuran. Seminar Bioteknologi Kelautan Indonesia I '98. Jakarta, 14-15 Oktober 1998.

Sutjiatmo, A.B. dan Sugiarso. 1996. Efek ekstrak etanol daun sambiloto terhadap tukak lambung yang disebabkan oleh Indometasin. Warta Tumbuhan Obat Indonesia, 3(1): 33-34.

Szeja, W. 1991. Convenient synthesis and application of sucrose sulfates. In: Lichtenhaler, F. W. (Ed.) Carbohydrates as Organic Raw Materials. VCH, New York. p. 117-123

Tan, H.T. dan Rahardja, K. 1991. Obat-Obat Penting. Khasiat. Penggunaan dan Efek-Efek Sampingnya. Edisi 4. p. 179-187 
Lampiran 1. Pemberian nilai tukak lambung berdasarkan jumlah tukak

Appendix 1. Scoring of peptic ulcer based on the total ulcer

\begin{tabular}{lc}
\hline $\begin{array}{c}\text { Kondisi/jumlah tukak lambung } \\
\text { Condition/Total peptic ulcer }\end{array}$ & $\begin{array}{c}\text { Nilai } \\
\text { Score }\end{array}$ \\
\hline Lambung normal (Normal stomach) & 1 \\
Merah/kemerahan (Red/reddish) & 1.5 \\
Hemoragi (Haemorrhage) & 2 \\
Bintik perdarahan (Spot bleeding) & 2 \\
Jumlah tukak (Total ulcer): 1-3 & 3 \\
Jumlah tukak (Total ulcer): 4-6 & 4 \\
Jumlah tukak (Total ulcer):7-9 & 5 \\
Jumlah tukak (Total ulcer): $>9$ & 6 \\
\hline
\end{tabular}

Lampiran 2. Pemberian nilai tukak lambung berdasarkan keparahan tukak Appendix 2. Scoring of peptic ulcer based on the seriousness of ulcer

\begin{tabular}{lc}
\hline $\begin{array}{c}\text { Kondisi/Keparahan tukak lambung } \\
\text { Condition/Seriousness of peptic ulcer }\end{array}$ & $\begin{array}{c}\text { Nilai } \\
\text { Score }\end{array}$ \\
\hline Lambung normal (Normal stomach) & 1 \\
Merah/kemerahan (Red/reddish) & 1.5 \\
Panjang tukak (Length of ulcer): $<0.5 \mathrm{~mm}$ & 2 \\
Panjang tukak (Length of ulcer): $<0.5-1.5 \mathrm{~mm}$ & 3 \\
Panjang tukak (Length of ulcer): $1.6-4.0 \mathrm{~mm}$ & 4 \\
Panjang tukak (Length of ulcer): $>4 \mathrm{~mm}$ & 5 \\
Perforasi (Perforation) & 6 \\
\hline
\end{tabular}

Lampiran 3. Nilai peringkat tukak lambung berdasarkan jumlah tukak Appendix 3. Ranking score of peptic ulcer based on the total ulcer

\begin{tabular}{cccccc}
\hline $\begin{array}{c}\text { Ulangan } \\
\text { Replication }\end{array}$ & \multicolumn{5}{c}{ Kelom pok perlakuan (Group of treatment) } \\
\cline { 2 - 6 } & I & II & III & IV & V \\
\hline 1 & 29 & 20 & 17 & 4.5 & 12 \\
2 & 24.5 & 24.5 & 12 & 4.5 & 4.5 \\
3 & 24.5 & 24.5 & 12 & 4.5 & 4.5 \\
4 & 24.5 & 20 & 17 & 4.5 & 12 \\
5 & 29 & 20 & 12 & 12 & 4.5 \\
6 & 29 & 24.5 & 17 & 12 & 4.5 \\
\hline Total (Total) & 160.5 & 133.5 & 87 & 42 & 42 \\
\hline Rata-rata (Mean) & 26.75 & 22.25 & 14.5 & 7 & 7 \\
\hline
\end{tabular}


Lampiran 4. Nilai peringkat tukak lambung berdasarkan keparahan tukak

Appendix 4. Ranking score of peptic ulcer based on the seriousness of ulcer

\begin{tabular}{cccccc}
\hline \multirow{2}{*}{$\begin{array}{c}\text { Ulangan } \\
\text { Replication }\end{array}$} & \multicolumn{5}{c}{ Kelom pok perlakuan (Group of treatment) } \\
\cline { 2 - 6 } & I & II & III & IV & V \\
\hline 1 & 27 & 27 & 17 & 4.5 & 12 \\
2 & 27 & 27 & 12 & 4.5 & 4.5 \\
3 & 21 & 27 & 12 & 4.5 & 4.5 \\
4 & 27 & 21 & 17 & 4.5 & 12 \\
5 & 27 & 21 & 12 & 12 & 4.5 \\
6 & 21 & 21 & 17 & 12 & 4.5 \\
\hline Total (Total) & 150 & 144 & 87 & 42 & 42 \\
\hline Rata-rata (Mean) & 25 & 24 & 14.5 & 7 & 7 \\
\hline
\end{tabular}

